\title{
Evaluation of Nootropic Potential of Leucaena leucocephala on Wister Rats
}

\author{
Jesanto Mathew ${ }^{1}$, Chakrakodi Shashidhara Shastry ${ }^{1, *}$, Sharad Chand ${ }^{2}$ \\ ${ }^{1}$ Department of Pharmacology, NGSM Institute of Pharmaceutical Sciences, Paneer, Nitte (Deemed to be University), Deralakatte, \\ Mangaluru- 575018, India \\ ${ }^{2}$ Department of Pharmacy Practice, NGSM Institute of Pharmaceutical Sciences, Nitte (Deemed to be University), Deralakatte, \\ Mangaluru- 575018, India
}

Received May 4, 2021; Revised August 6, 2021; Accepted October 22, 2021

\section{Cite This Paper in the following Citation Styles}

(a): [1] Jesanto Mathew, Chakrakodi Shashidhara Shastry, Sharad Chand, "Evaluation of Nootropic Potential of Leucaena leucocephala on Wister Rats, "Advances in Pharmacology and Pharmacy, Vol. 10, No. 1, pp. 8 - 17, 2022. DOI: 10.13189/app.2022.100102.

(b): Jesanto Mathew, Chakrakodi Shashidhara Shastry, Sharad Chand (2022). Evaluation of Nootropic Potential of Leucaena leucocephala on Wister Rats. Advances in Pharmacology and Pharmacy, 10(1), 8 - 17. DOI: 10.13189/app.2022.100102.

Copyright $\bigcirc 2022$ by authors, all rights reserved. Authors agree that this article remains permanently open access under the terms of the Creative Commons Attribution License 4.0 International License

\begin{abstract}
Introduction: Leucaena leucocephala is a commonly used plant in the Ayurveda system of medicine to alleviate several ailments. Different parts of Leucaena leucocephala are used for the treatment of ailments such as diabetes, ascariasis, intestinal parasitism and trichinosis. It is also used as an emmenagogue, emollient and as nutritious forage for cattle. Objective: This study was conducted to evaluate the plant extract's effect on memory and learning using in-vivo models and ex-vivo models. Methods: The plant extract was prepared by using the Soxhlet extraction procedure. The effect of the extract on nootropic activity was assessed against scopolamine-induced amnesia using different exteroceptive models such as Elevated plus maze, Y maze and Hebb William's maze. Acetylcholinesterase activity of the rat brain homogenate was estimated using Ellman's method. The activity of the extract was compared with the standard drug piracetam. Results: On pre-treatment with ethanolic extract of $L$. leucocephala, in-vivo studies showed significantly improved spatial learning and memory against scopolamine-induced amnesia in Wistar rat models in a dose-dependent manner. Ex-vivo studies of rat whole brain homogenate showed a significant decrease in acetylcholinesterase activity in extract-treated animals. Conclusion: The ethanolic extract of the leaves of $L$. leucocephala showed significant nootropic potential against animals induced by amnesia using scopolamine.
\end{abstract}

Keywords Anticholinesterase, Cognition, Elevated Plus Maze, Hebb Williams Maze, Nootropic Potential, Y Maze

\section{Introduction}

In the treatment of memory disorders like Alzheimer's disease, the structural diversity of the phytoconstituents present in the plants makes them a potential lead compound for the quest of drugs for the treatment [1]. Cognition is the ability of the brain to comprehend, store and retrieve the sequences of information experienced through the sensory organs [2,3]. Large numbers of plants are being screened for their nootropic, memory enhancing activity. Plants such as bacopa monnieri, acorus calamus, withania somnifera, evolulus alsinoides, emblica officinalis, centella asiatica, zinzziber officinale, celastrus panniculatus, vitis vinifera, thespesia populnea, Panax ginseng, Prunus amygdalus, Clitoria ternatea $L$., Hypericum perforatum, Cornus officinalis, Glycyrrhiza glabra and Pueraria tuberose have showed significant memory enhancing activity [3].L. leucocephalahas has its origin in Central America where it has been recognised for its fodder values over 400 years ago. Now it is widely spread over Southern Asia and neighbouring islands [4]. 
Flavonoids like Isorhamnetin, Caffeic acid, Chrysoeriol, isorhamnetin 3-o-galactoside, Kaempferol-3-o-rubinoside, Quercetin-3-o-rhamnoside, Luteolin-7-o-glucoside) [5] Polyprenols like Ficaprenol, Terpenoids like Squalene, Lupeol, Steroid like $B$-sitostenone [6], $\beta$-sitosterol, stig-mastenone [7], Tannins like Gallic acid, Flavone [8], Chlorophylls like aristophyll-c $\mathrm{c}^{5}$ are present in the L. leucocenphala. Antidiabetic [9], Antiproliferative [10], Anthelmintic [11], Antimicrobial [12], Nutritive [13], anti-piles [14], Hypoglycemic and Hypolipidemic [15] activities of $L$. leucocephala have been reported in the literature. A limited study has been carried out on the nootropic activity using L. leucocephala. Dzoyem JP et al. reported the anti-inflammatory, antioxidant activity and Acetylcholine esterase inhibitor properties of the plant. Since antioxidants offer a neuroprotective effect, they can be potential molecules for investigation [10]. With this hypothesis, the present study was carried out to assess the nootropic effect of $L$. leucocephala leaves' extract based of antioxidant and acetylcholine esterase inhibitory activity of the plant extract reported earlier.

\section{Materials and Methods}

The systematic approach of the study procedure is illustrated in the Figure 1.

\subsection{Materials}

The chemicals used in the study were of analytical grade. Scopalamine, piracetam, and acetylcholine iodine were procured from Sigma Aldrich, St. Louis, USA. Chemical including anhydrous calcium chloride, sodium carboxy methyl cellulose, potassium dihydrogen citrate was procured from Loba Chemie Pvt. Ltd., Mumbai, hydroxymethyl hydrochloride (Tris HCL) and Ellman's reagent from Himedia, sodium hydroxide and ethanol from Merck Pvt. Ltd., Mumbai and Methanol was procured from Nice chemicals Pvt. Ltd. Kochi, Kerala.

\section{Systemic procedure of the research study}

Identification and collection of leaves of Leucaena leucocephala

$\checkmark$ Extraction by Soxhlet extractor

preparation of ethanolic extract from the leaves

Using the standard methods

Preliminary qualitative phytochemical investigation

Obtained ethical approval

Animal studies

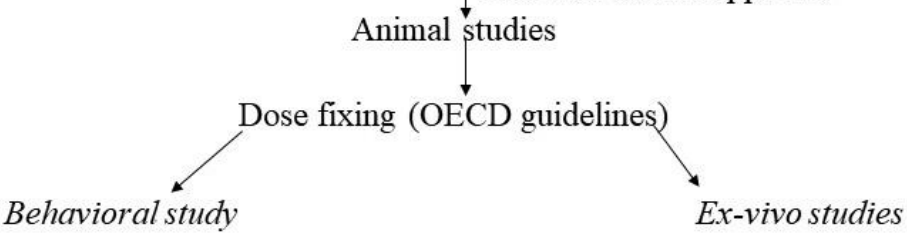

1) Elevated plus-maze study

2) Y-maze model study

3) Hebb-Williams maze study
1) Estimation of AChE by Ellman's method

2) Estimation of $\mathrm{AChE}$ by microplate assay

Statistical analysis and data interpretation

Evaluation of Nootropic potential and conclusion

Figure 1. Schematic presentation of study procedure 


\subsection{Preparation of Extract}

The leaves of Leucaena leucocephala were collected from Deralakatte, Mangalore, Karnataka, India. The leaves were collected during the month of July 2016. Plant was authenticated by Dr. K.V. Nagalakshamma, Associate Professor, HoD, Department of Botony, St. Aloysius College, (Autonomous) Mangalore-575003. Voucher specimen was kept in the herbarium of the institute. The leaves were washed and dried under shade at room temperature. The dried leaves crushed into a coarse powder. Seven hundred grams of coarse powder was extracted with ethanol by Soxhlet extractor for five cycles. The extract was concentrated using a rotary flash evaporator under reduced pressure. However, we could not get pure dry powder using the rotary flash evaporator. The greenish brown viscous extract obtained was stored in a desiccator free from moisture and humidity. The percentage yield of the viscous extract was 12 .

\subsection{Preliminary Qualitative Phytochemical Investigation}

Qualitative phytochemical examination of the ethanolic extract of leaves of $L$. leucocephala was carried out using standard methods for alkaloids (Dragendroff's test, Hager's test, Wagner's test, Mayer's test), reducing sugar (Molisch test, Benedict's test, Fehling's test, Tollen's test), flavonoids (Shinoda test), saponins, tannins, steroids (Libermann-Burchard's test, Salkowski reaction), proteins (Biuret test, Millon's test) and tritrepenoids (Libermann-Burchard's test) [16,17].

\subsection{Animals}

Albino Wistar rats of either sex, weighing 150-200 g, were obtained from the committee for the purpose of control and supervision of experiments on animals (CPCSEA) approved animal house of Nitte Gulabi Shetty Memorial Institute of Pharmaceutical Sciences (Ref.1781/PO/EReBi/S/2014/CPCSEA), Mangalore, India. After being divided into different groups, all the animals were kept in separate cages, with free access to food (standard dry pellet diet) and water ad libitum. These animals were kept at a temperature of $23-27^{\circ} \mathrm{C}$ with light and dark cycle of $12 \mathrm{hrs}$ following the standard laboratory conditions. The bedding used for the animals was a paddy husk, which was changed at least twice a week. After the completion of experiment the animals were anaesthetized and the animals were sacrificed by cervical dislocation.

\subsection{Selection of Dose}

Three dose levels were selected namely $200 \mathrm{mg} / \mathrm{kg}$, 400 $\mathrm{mg} / \mathrm{kg}$ and $800 \mathrm{mg} / \mathrm{kg}$ body weight based on acute toxicity study result. The extract was found to be nontoxic and safe when tested at a dose level of $2000 \mathrm{mg} / \mathrm{kg}$. The test was carried out as per organization for economic co-operation and development (OECD) guideline 425, up and down method (Acute oral toxicity test). As we predicted low toxicity of the extract, a single dose of 2000 $\mathrm{mg} / \mathrm{kg}$ body weight was administered orally using a gavage needle to a female rat weighing $180 \mathrm{~g}$. The animal was observed for 4 hours continuously and later on daily basis for any toxic CNS, CVS, and autonomic symptoms. No morbidity or mortality was observed during the observation period.

\subsection{Treatment Schedule and Evaluation of Nootropic Activity}

Forty-eight albino, Wistar rats of either sex, weighing about $150-200 \mathrm{~g}$ were divided into eight groups of six animals each (i.e., $n=6$ ) for the study. Group I served as normal control and received the formulation vehicle $(0.6 \%$ w/v sodium CMC, $10 \mathrm{ml} / \mathrm{kg}$, once daily, oral). Group II received scopolamine $\left(1 \mathrm{mg} / \mathrm{kg}\right.$, i.p.) only on the $8^{\text {th }}$ day of the study. Piracetam $(200 \mathrm{mg} / \mathrm{kg}$, oral, once a day for 8 days) and L. leucocephala extract $(800 \mathrm{mg} / \mathrm{kg}$, oral, once a day for 8 days) were administered to groups III and IV. Animals of groups V, VI, VII and VIII were administered with standard piracetam and test compounds for eight days and on the $8^{\text {th }}$ day; amnesia was induced with one dose of scopolamine $(1 \mathrm{mg} / \mathrm{kg})$. After 45 minutes of administration of the test drug, the nootropic activity was assessed using three maze-models: Elevated plus maze, Y-maze, and Hebb-William's maze. The trials were carried out again on the next day ( $9^{\text {th }}$ day) $24 \mathrm{hrs}$. Since the first exposure and the retention index was recorded, this served as the scale for determining the nootropic potential of the drug.

\subsection{Maze Models}

\subsubsection{Elevated plus-maze}

This model is an incentive based exteroceptive model which is used for the screening of nootropic agents and anxiolytics. The apparatus has two closed and two open arms with a length of $50 \mathrm{~cm}$ and a width of $10 \mathrm{~cm}$ and are perpendicular to each other. The maze has an elevated position, which is $50 \mathrm{~cm}$ from the ground. For taking the trial, the animal was placed in one of the open arms of the maze such that the animal faced away from the central platform. The animal was observed and the time taken by the rat to reach the closed arm from the open arm was recorded as the initial transfer latency (ITL). For all the trials, the cut-off time was 90 seconds. A similar trial was carried after $24 \mathrm{hr}$ of the ITL and that was recorded as the retention transfer latency (RTL). These both recorded parameters were designated as acquisition (learning/ITL) and retention (memory/RTL), respectively $[18,19] \mathrm{A}$ decline in the transfer latency on repeated maze exposures will be graded as successful memory retention. 
From the above observations, inflexion ration (IR) was calculated:

$$
\begin{gathered}
\mathrm{IR}=\mathrm{L}_{0}-\mathrm{L}_{1} / \mathrm{L}_{1} \\
\mathrm{IR}=\text { Inflexion ratio } \\
\mathrm{L}_{0}=\text { Initial transfer latency (In sec) } \\
\mathrm{L}_{1}=\text { Retention transfer latency }(\text { In sec) }
\end{gathered}
$$

\subsubsection{Y-maze}

The spatial working memory in rodents was determined by using Y-Maze. This model is based on the constant altering behaviour of animals. In Y-maze, there are three horizontal arms that are aligned at an angle of $120^{\circ}$. The maze arms are of length $40 \mathrm{~cm}, 3 \mathrm{~cm}$ in width, and $12 \mathrm{~cm}$ high walls. The three arms may be labeled as start arm (A), a reward arm having food (B), and a random arm (C). The maze is made of dark polyvinyl plastic, which is opaque. With food as a reward, the animals are allowed to perform a suitable search operation. This index is used in temporal measurement and error scoring, which are the intricate parameters to evaluate the retention ability in a given drug known to possess nootropic activity. All the animals should properly be trained before subjecting them to test [20].

For the trial, the animals were placed on the start arm and were allowed to move all through the maze for 8 mins, and every arm entry was recorded. The alternating behaviour of animals was expressed when the animals know which arm it has already visited. The arm re-entry was tabulated in the form of a triad, which were $A B C$ or $\mathrm{BCA}$ or $\mathrm{CAB}$ or $\mathrm{ACB}$, and so on. The triad was only considered if the animal shows alternating arm entries and not repeated entry, i.e., $\mathrm{ABA}$ or $\mathrm{BCB}$ or $\mathrm{CBC}$, and so on. Short-term memory retention was assessed using this alteration. From the recorded arm entries and the alterations, the $\%$ alterations were calculated using the formula.

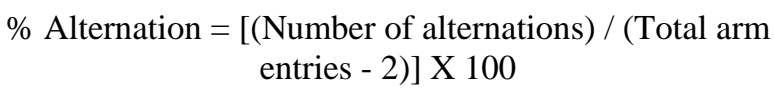

\subsubsection{Hebb-William's maze}

Spatial memory, as well as working memory, can be determined using the Hebb-Williams maze, which is an exteroceptive model having three chambers that are used to assess animal behaviour. With the help of a wooden partition, chambers are detached from each other. The animal is kept in the first chamber, which is called the start box. The second chamber consists of a twisted corridor that separates the start box and the reward area [21]. This area is called an exploratory area. The animal fasts overnight. For taking a trial, the animal was placed in the start box. The time taken for the animal to get to the reward chamber was noted. A zero-watt red colour bulb was used to prevent any nocturnal interruptions during the test. ITL was noted on the first day of the test $\left(8^{\text {th }}\right.$ day of drug treatment). For an additional 3 minutes, the animals were allowed to explore all over the maze. The animals were then exposed to food for $1 \mathrm{hr}$ to bring about stimulation. RTL was determined on the next day. Both the values were taken, and the IR was calculated [22].

\subsection{Ex-vivo Studies}

\subsubsection{Collection of brain samples}

Rats were anesthetized and sacrificed humanely after the experiments. The skull was cut open, and the whole brain was removed carefully, weighed and washed using cold saline in a cold bath and homogenized. The brain was homogenized using Potter-Elvehjem homogenizer $(20 \mathrm{mg}$ of brain tissue in one $\mathrm{ml}$ of $0.1 \mathrm{M}$ phosphate buffer). Acetylcholine esterase activity was estimated by using the supernatant liquid separated from the homogenate after centrifuging it for 10 minutes at a speed of 3000 rotation per minute [23].

\subsubsection{Estimation of acetylcholinesterase activity by Ellman's method}

Acetylcholine esterase is an enzyme, whose main function is hydrolysis of acetylcholine which results in the termination of transmission of cholinergic synapses. So, in cognitive dysfunctions like Alzheimer's diseases, AChE is considered to cause extensive loss of cholinergic neurons in the brain [24]. Ellman's method is used to determine the AChE activity. In this method AChE acts on Acetyl thiocholine (ATC), which is an artificial substrate and results in the release of thiocholine and acetic acid. Further this thiocholine is made to react with $-\mathrm{SH}$ reagent 5,5-dithio-bis-(2, nitro benzoic acid) (DTNB), resulting in the conversion of thiocholine to thionitro benzoic acid, a yellow-coloured anion with absorption maxima $412 \mathrm{~nm}$. $1.36 \times 10-4 / \mathrm{molar} / \mathrm{cm}$ is the molar extinction coefficient of thionitrobenzoic acid. By using UV spectrophotometer, the concentration of thionitro benzoic acid is determined which is directly proportional to the AChE activity [25].

\subsubsection{Estimation of Acetylcholinesterase by microplate assay}

Acetylcholinesterase activity was measured using 96-well microplate reader based on Ellman's method. In the 96-well plates, $25 \mu \mathrm{l}$ of $15 \mathrm{mM}$ ACTI in water, $125 \mu \mathrm{l}$ of samples of $3 \mathrm{~m} M$ DTNB in buffer C $(50 \mathrm{~m} M$ Tris-hydrochloric acid, $\mathrm{pH} 8$, containing $0.1 \mathrm{M} \mathrm{NaCl}$ and $0.02 \mathrm{M}$ magnesium chloride), $50 \mu$ l of buffer B $(50 \mathrm{mM}$ Tris- $\mathrm{HCl}, \mathrm{pH} 8$, comprising $0.1 \%$ bovine serum Albumin), $25 \mu \mathrm{l}$ of samples $(10 \mathrm{mg} / \mathrm{ml}$, in methyl alcohol, diluted ten times with buffer A were added. The absorbance was measured at $405 \mathrm{~nm}$ every 13 seconds for 5 times [26,27].

\subsection{Statistical Analysis}

The recorded data were expressed in terms of Mean \pm 
SEM and analyzed in statistical package for the social science (SPSS version 20.0) using one way analysis of variance (ANOVA) and post hoc Scheffe's test. The findings were interpreted for possible activity. A p-value of less than 0.05 was considered statistically significant.

\section{Results}

\subsection{Preliminary Phytochemical Analysis of an Ethanolic Extract of L. Leucocephala Leaves}

The extract was analyzed for the presence of alkaloids, reducing sugars, flavonoids, tannins, saponins, steroids, proteins and triterpenoids using standard methods stated earlier. The extract showed the presence of all the phytoconstituents stated above. The results are given in Table 1. However, we have not carried out quantitative estimation of these compounds in the present study.

Table 1. Phytochemical evaluation of ethanolic extract of $L$. leucocephala leaves

\begin{tabular}{|c|c|c|}
\hline Phytoconstituents & Test & Result \\
\hline \multirow{3}{*}{ Alkaloids } & Dragendroff's test & + \\
& Hager's test & + \\
& Wagner's test & + \\
& Mayer's test & + \\
\hline \multirow{2}{*}{ Reducing sugars } & Molisch's test & + \\
& Benedict's test & + \\
& Fehling's test & + \\
\hline Flavonoids & Tollen's test & + \\
\hline Tannins & Shinoda test & + \\
\hline Saponins & & + \\
\hline Steroids & Libermann-Burchard's test & + \\
\hline Proteins & Salkowski test & + \\
\hline Triterpenoids & Biuret test & + \\
\hline
\end{tabular}

\subsection{Acute Toxicity Studies}

Acute toxicity study was carried out using female albino rats. The ethanolic extract of the leaves of $L$. leucocephala was found to be safe at a dose level of 2000 $\mathrm{mg} / \mathrm{kg}$ body weight when administered by oral route. The animals were observed for 24 hours for any sign of toxicity following oral administration of the extract suspension (single dose). Even after 24 hours animals were found well tolerated. There were no signs of toxicity, morbidity or mortality. The observations are given in Table 2.

Table 2. Acute toxicity study observations

\begin{tabular}{|c|c|c|c|}
\hline signs & observation & signs & observation \\
\hline Motor activity & Normal & Ataxia & Absent \\
\hline Tremors & Absent & Lighting reflex & Normal \\
\hline $\begin{array}{c}\text { Clonic } \\
\text { convulsion } \\
\end{array}$ & Absent & Sedation & Absent \\
\hline Straub reaction & Absent & $\begin{array}{l}\text { Muscle } \\
\text { relaxation }\end{array}$ & Absent \\
\hline Pilo-erection & Absent & $\begin{array}{l}\text { Arching and } \\
\text { rolling }\end{array}$ & Absent \\
\hline Muscle spasm & Absent & Ptosis & Absent \\
\hline catatonia & Absent & Lacrimation & Normal \\
\hline Exophthalmos & Absent & Writhing & Absent \\
\hline Diarrhoea & Absent & $\begin{array}{c}\text { Reparation: } \\
\text { Depression } \\
\text { Stimulation } \\
\text { Failure }\end{array}$ & Normal \\
\hline $\begin{array}{c}\text { Salivation: } \\
\text { Viscid } \\
\text { Watery }\end{array}$ & Normal & $\begin{array}{l}\text { Skin colour: } \\
\text { Blanching } \\
\text { Cyanosis } \\
\text { Vasodilatation }\end{array}$ & Normal \\
\hline
\end{tabular}

\subsection{Elevated Plus-Maze}

Evaluation of the nootropic potential of the ethanolic extract of L. leucocephala was carried out using elevated plus-maze. The result showed that those groups of animals in which amnesia was induced by scopolamine $(1 \mathrm{mg} / \mathrm{kg}$ b.w. i.p.) after pre-treatment with L. leucocephala (200 $\mathrm{mg} / \mathrm{kg}, 400 \mathrm{mg} / \mathrm{kg}$ and $800 \mathrm{mg} / \mathrm{kg}$ ) for eight days showed significant decrease in ITL, when compared to normal group as well as scopolamine challenged group. The results are shown in Table 3. 
Table 3. Effect of L. leucocephala extract on transfer latency using elevated plus maze

\begin{tabular}{|c|c|c|c|c|}
\hline Groups & Treatment $(\mathbf{n}=\mathbf{6})$ & $\begin{array}{c}\text { ITL } \\
(\mathbf{s e c s})\end{array}$ & $\begin{array}{c}\text { RTL } \\
\text { (secs) }\end{array}$ & Inflexion Ratio \\
\hline Normal control & Normal (Vehicle) & $47.50 \pm 0.56$ & $43.35 \pm .88$ & $0.109 \pm .01$ \\
\hline Disease control & Scopolamine $(1 \mathrm{mg} / \mathrm{kg})$ & $56.83 \pm 6.90$ & $51 \pm 4.03$ & $0.098 \pm .004$ \\
\hline Piracetam & Piracetam $(200 \mathrm{mg} / \mathrm{kg})$ & $20.16 \pm 2.16$ & $15 \pm 2.74$ & $0.575 \pm .271$ \\
\hline Extract & L. leucocephala $(800 \mathrm{mg} / \mathrm{kg})$ & $23.33 \pm 3.21$ & $17.16 \pm 2.18$ & $0.357 \pm .062$ \\
\hline Standard & Piracetam $(200 \mathrm{mg} / \mathrm{kg})+$ Scopolamine $(1 \mathrm{mg} / \mathrm{kg})$ & $25 \pm 2.80$ & $18.35 \pm 2.13$ & $0.394 \pm .176$ \\
\hline T-1 & $\begin{array}{c}\text { Extract }(200 \mathrm{mg} / \mathrm{kg})+ \\
\text { Scopolamine }(1 \mathrm{mg} / \mathrm{kg})\end{array}$ & $40 \pm 4.44$ & $34.33 \pm 3.83^{\mathrm{b}}$ & $0.153 \pm .034^{\mathrm{b}}$ \\
\hline $\mathrm{T}-2$ & $\begin{array}{c}\text { Extract }(400 \mathrm{mg} / \mathrm{kg})+ \\
\text { Scopolamine }(1 \mathrm{mg} / \mathrm{kg})\end{array}$ & $33 \pm 5.47^{\mathrm{a}}$ & $26.83 \pm 4.19^{\mathrm{b}}$ & $0.224 \pm .035^{\mathrm{b}}$ \\
\hline $\mathrm{T}-3$ & $\begin{array}{c}\text { Extract }(800 \mathrm{mg} / \mathrm{kg})+ \\
\text { Scopolamine }(1 \mathrm{mg} / \mathrm{kg})\end{array}$ & $26.16 \pm 2.18^{\mathrm{a}}$ & $19.83 \pm 1.55^{\mathrm{b}}$ & $0.318 \pm .045^{\mathrm{a}}$ \\
\hline
\end{tabular}

$\mathrm{a}=\mathrm{p}<0.05, \mathrm{~b}=\mathrm{p}<0.05$ when compared to disease control group of ITL and RTL respectively.

Table 4. Effect of L. leucocephala extract on transfer latency using Hebb-Williams Maze

\begin{tabular}{|c|c|c|c|}
\hline Groups & Treatment $(\mathbf{n}=\mathbf{6})$ & ITL (secs) & RTL (secs) \\
\hline Normal control & Normal $($ Vehicle) & $129.5 \pm 10.99$ & $108.8 \pm 8.79$ \\
\hline Disease control & Scopolamine $(1 \mathrm{mg} / \mathrm{kg})$ & $149.67 \pm 10.69$ & $132.8 \pm 9.05$ \\
\hline Piracetam & Piracetam $(200 \mathrm{mg} / \mathrm{kg})$ & $35.83 \pm 3.09$ & $26 \pm 3.87^{\mathrm{b}}$ \\
\hline Extract & L. leucocephala $(800 \mathrm{mg} / \mathrm{kg})$ & $40.66 \pm 1.78$ & $32.66 \pm 1.56$ \\
\hline Standard & $\begin{array}{c}\text { Piracetam }(200 \mathrm{mg} / \mathrm{kg})+ \\
\text { Scopolamine }(1 \mathrm{mg} / \mathrm{kg})\end{array}$ & $37.83 \pm 1.95$ & $28.33 \pm 1.76$ \\
\hline $\mathrm{T}-1$ & Extract $(200 \mathrm{mg} / \mathrm{kg})+$ Scopolamine $(1 \mathrm{mg} / \mathrm{kg})$ & $50.16 \pm 4.20^{\mathrm{a}}$ & $44.50 \pm 3.93^{\mathrm{b}}$ \\
\hline $\mathrm{T}-2$ & Extract $(400 \mathrm{mg} / \mathrm{kg})+$ Scopolamine $(1 \mathrm{mg} / \mathrm{kg})$ & $43.66 \pm 4.50^{\mathrm{a}}$ & $35.50 \pm 3.50^{\mathrm{b}}$ \\
\hline $\mathrm{T}-3$ & Extract $(800 \mathrm{mg} / \mathrm{kg})+$ Scopolamine $(1 \mathrm{mg} / \mathrm{kg})$ & $41.66 \pm 5.12^{\mathrm{a}}$ & $33 \pm 4.35^{\mathrm{b}}$ \\
\hline
\end{tabular}

$\mathrm{a}=\mathrm{p}<0.05, \mathrm{~b}=\mathrm{p}<0.05$ when compared to disease control group

Table 5. Effect of L. leucocephala extract on the number of arm entries using Y maze

\begin{tabular}{|c|c|c|c|}
\hline Groups & Treatment (n=6) & $\begin{array}{c}\text { No. of arm entries on day 8 (Mean } \\
\pm \text { SEM) }\end{array}$ & $\begin{array}{c}\text { No. of arm entries on day 9 (Mean } \\
\pm \text { SEM) }\end{array}$ \\
\hline $\begin{array}{c}\text { Normal } \\
\text { control }\end{array}$ & Normal (Vehicle) & $27.5 \pm .76$ & $22.16 \pm .47$ \\
\hline $\begin{array}{c}\text { Disease } \\
\text { control }\end{array}$ & Scopolamine $(1 \mathrm{mg} / \mathrm{kg})$ & $32.3 \pm 2.57$ & $26.16 \pm 1.77$ \\
\hline Piracetam & Piracetam $(200 \mathrm{mg} / \mathrm{kg})$ & $14.5 \pm 2.30$ & $10.83 \pm 1.62$ \\
\hline Extract & L. leucocephala $(800 \mathrm{mg} / \mathrm{kg})$ & $15 \pm 1.34$ & $11.16 \pm 1.13$ \\
\hline Standard & $\begin{array}{c}\text { Piracetam }(200 \mathrm{mg} / \mathrm{kg})+ \\
\text { Scopolamine }(1 \mathrm{mg} / \mathrm{kg})\end{array}$ & $16.5 \pm 3.32$ & $14.83 \pm 1.7^{\mathrm{b}}$ \\
\hline $\mathrm{T}-1$ & $\begin{array}{c}\text { Extract }(200 \mathrm{mg} / \mathrm{kg})+ \\
\text { Scopolamine }(1 \mathrm{mg} / \mathrm{kg})\end{array}$ & $20.16 \pm 2.30^{\mathrm{a}}$ & $14.16 \pm 1.19^{\mathrm{b}}$ \\
\hline $\mathrm{T}-2$ & $\begin{array}{c}\text { Extract }(400 \mathrm{mg} / \mathrm{kg})+\mathrm{Scopolamine}(1 \\
\mathrm{mg} / \mathrm{kg})\end{array}$ & $18 \pm 2.26^{\mathrm{a}}$ & $13 \pm 1^{\mathrm{b}}$ \\
\hline $\mathrm{T}-3$ & $\begin{array}{c}\text { Extract }(800 \mathrm{mg} / \mathrm{kg})+ \\
\text { Scopolamine }(1 \mathrm{mg} / \mathrm{kg})\end{array}$ & $17.3 \pm 1.20^{\mathrm{a}}$ & \\
\hline
\end{tabular}

$\mathrm{a}=\mathrm{p}<0.05, \mathrm{~b}=\mathrm{p}<0.05$ when compared to disease control group

\subsection{Hebb-William's Maze}

The result suggested that those groups of animals in which amnesia was induced by scopolamine $(1 \mathrm{mg} / \mathrm{kg}$ b.w. i.p.) after pre-treatment with L. leucocephala $(200 \mathrm{mg} / \mathrm{kg}$, $400 \mathrm{mg} / \mathrm{kg}$ and $800 \mathrm{mg} / \mathrm{kg}$ ) for successive eight days showed a significant decrease in ITL, when compared to normal group as well as scopolamine challenged group.
Data are illustrated in Table 4.

\subsection{Y Maze}

3.5.1. Effect on the number of arm entries

Groups in which the amnesia was induced by scopolamine $(1 \mathrm{mg} / \mathrm{kg}$ i.p) after pre-treatment with the 
extract $(200 \mathrm{mg} / \mathrm{kg}, 400 \mathrm{mg} / \mathrm{kg}$, and $800 \mathrm{mg} / \mathrm{kg}$ ) for eight days successively showed a significant decrease in the number of arm entries when compared to the normal group and the scopolamine challenged group. The results are shown in Table 5.

\subsubsection{Effect on $\%$ alterations}

Group of animals in which the amnesia was induced by giving scopolamine $(1 \mathrm{mg} / \mathrm{kg}$ i.p) on pre-treatment with extract $(200 \mathrm{mg} / \mathrm{kg}, 400 \mathrm{mg} / \mathrm{kg}, 800 \mathrm{mg} / \mathrm{kg})$ successively for eight days showed a significant dose-dependent increase in the $\%$ alterations when compared to the scopolamine treated group and results were almost comparable with normal groups. Percentage alteration increased in all the extract and in piracetam treated group when compared to the normal group. The detailed information is referenced in Table 6.

\subsection{Biochemical Estimation}

\subsubsection{Estimation of acetylcholinesterase (AchE) activity}

The result of the study showed a significant increase of AchE in the whole brain upon treatment with scopolamine at a dose of $1 \mathrm{mg} / \mathrm{kg}$ body weight (i.p.). The amnesia induced group showed a significant dose-dependent decline in AchE when pre-treated with L. leucocephala (200 mg/kg, $400 \mathrm{mg} / \mathrm{kg}$ and $800 \mathrm{mg} / \mathrm{kg}$ ) successively for eight days as compared with the scopolamine challenged group. The results are depicted in Table 7.

Table 6. Effect of L. leucocephala extract on \% Alteration using Y maze

\begin{tabular}{|c|c|c|c|}
\hline Groups & Treatment $(\mathbf{n}=\mathbf{6})$ & \% Alteration $^{\text {th }}$ day & \% Alteration $^{\text {th }}$ day \\
\hline Normal control & Normal $($ Vehicle $)$ & $23.18 \pm 1.20$ & $24.66 \pm .95$ \\
\hline Disease control & Scopolamine $(1 \mathrm{mg} / \mathrm{kg})$ & $14.72 \pm .92$ & $13.87 \pm 1.22$ \\
\hline Piracetam & Piracetam $(200 \mathrm{mg} / \mathrm{kg})$ & $27.12 \pm 3.39$ & $28.73 \pm 1.94$ \\
\hline Extract & L. leucocephala $(800 \mathrm{mg} / \mathrm{kg})$ & $25.83 \pm 1.71$ & $27.94 \pm 1.58$ \\
\hline Standard & $\begin{array}{c}\text { Piracetam }(200 \mathrm{mg} / \mathrm{kg})+ \\
\text { Scopolamine }(1 \mathrm{mg} / \mathrm{kg})\end{array}$ & $26.84 \pm 1.65$ & $29.12 \pm 2.69$ \\
\hline $\mathrm{T}-1$ & Extract $(200 \mathrm{mg} / \mathrm{kg})+$ Scopolamine $(1 \mathrm{mg} / \mathrm{kg})$ & $22.58 \pm 1.38$ & $24.65 \pm 1.34^{\mathrm{b}}$ \\
\hline $\mathrm{T}-2$ & Extract $(400 \mathrm{mg} / \mathrm{kg})+$ Scopolamine $(1 \mathrm{mg} / \mathrm{kg})$ & $23.84 \pm 1.47$ & $25.41 \pm 1.51^{\mathrm{b}}$ \\
\hline $\mathrm{T}-3$ & Extract $(800 \mathrm{mg} / \mathrm{kg})+$ Scopolamine $(1 \mathrm{mg} / \mathrm{kg})$ & $25.37 \pm .37^{\mathrm{a}}$ & $27.42 \pm 1.25^{\mathrm{b}}$ \\
\hline
\end{tabular}

$\mathrm{a}=\mathrm{p}<0.05, \mathrm{~b}=\mathrm{p}<0.05$ when compared to disease control group

Table 7. Effect of L. leucocephala extract on whole-brain Acetyl cholinesterase

\begin{tabular}{|c|c|c|}
\hline Groups & Treatment & $\begin{array}{c}\text { Acetyl cholinesterase enzyme activity } \\
(\boldsymbol{\mu} \text { moles } / \text { min } / \text { g tissue })\end{array}$ \\
\hline Normal control & Normal $($ Vehicle $)$ & $1.89 \pm 0.089$ \\
\hline Disease control & Scopolamine $(1 \mathrm{mg} / \mathrm{kg})$ & $3.02 \pm 0.079$ \\
\hline Piracetam & Piracetam $(200 \mathrm{mg} / \mathrm{kg})$ & $1.65 \pm .041$ \\
\hline Extract & L. leucocephala $(800 \mathrm{mg} / \mathrm{kg})$ & $1.75 \pm 0.067$ \\
\hline Standard & Piracetam $(200 \mathrm{mg} / \mathrm{kg})+$ Scopolamine $(1 \mathrm{mg} / \mathrm{kg})$ & $1.95 \pm 0.65$ \\
\hline $\mathrm{T}-1$ & Extract $(200 \mathrm{mg} / \mathrm{kg})+$ Scopolamine $(1 \mathrm{mg} / \mathrm{kg})$ & $2.40 \pm 0.057^{\mathrm{b}}$ \\
\hline $\mathrm{T}-2$ & Extract $(400 \mathrm{mg} / \mathrm{kg})+$ Scopolamine $(1 \mathrm{mg} / \mathrm{kg})$ & $2.32 \pm 0.074^{\mathrm{b}}$ \\
\hline $\mathrm{T}-3$ & Extract $(800 \mathrm{mg} / \mathrm{kg})+$ Scopolamine $(1 \mathrm{mg} / \mathrm{kg})$ & $2.20 \pm 0.106^{\mathrm{b}}$ \\
\hline
\end{tabular}

$\mathrm{a}=\mathrm{p}<0.05$ when compared to the disease control group 
Table 8. Effect of L. leucocephala extract on \% Inhibition of acetylcholinesterase enzyme

\begin{tabular}{|c|c|c|c|c|c|c|}
\hline \multirow{2}{*}{ Groups } & Treatment (n=6) & \multicolumn{5}{|c|}{ \% Inhibition } \\
\cline { 3 - 7 } & $\mathbf{0}(\mathbf{s})$ & $\mathbf{1 3}(\mathbf{s})$ & $\mathbf{2 6}(\mathbf{s})$ & $\mathbf{3 9}(\mathbf{s})$ & $\mathbf{5 2}(\mathbf{s})$ \\
\hline $\begin{array}{c}\text { Normal } \\
\text { control }\end{array}$ & Normal (Vehicle) & $31.27 \pm 0.44$ & $21.7 \pm 2.9$ & $19.23 \pm 2.07$ & $12.9 \pm 1.55$ & $9.4 \pm 0.8$ \\
\hline $\begin{array}{c}\text { Disease } \\
\text { control }\end{array}$ & Scopolamine (1 mg/kg) & $25.95 \pm 0.6$ & $17.25 \pm 1.7$ & $15.3 \pm .85$ & $4.3 \pm 1.3$ & $7.5 \pm 1.37$ \\
\hline Piracetam & Piracetam (200 mg/kg) & $40.42 \pm 1.0^{\mathrm{a}, \mathrm{b}}$ & $37.21 \pm 2.7^{\mathrm{a}, \mathrm{b}}$ & $31.21 \pm 1.8^{\mathrm{a}, \mathrm{b}}$ & $23.1 \pm 2.67^{\mathrm{a}, \mathrm{b}}$ & $17.3 \pm 1.9^{\mathrm{a}, \mathrm{b}}$ \\
\hline Extract & $\begin{array}{c}\text { L. leucocephala }(800 \\
\mathrm{mg} / \mathrm{kg})\end{array}$ & $36.83 \pm 0.9^{\mathrm{a}, \mathrm{b}}$ & $34.31 \pm 0.9^{\mathrm{a}, \mathrm{b}}$ & $28.8 \pm 1.9^{\mathrm{b}}$ & $19.7 \pm 1.46^{\mathrm{b}}$ & $14.7 \pm 1.3$ \\
\hline Standard & $\begin{array}{c}\text { Piracetam }(200 \mathrm{mg} / \mathrm{kg})+ \\
\text { Scopolamine }(1 \mathrm{mg} / \mathrm{kg})\end{array}$ & $36.5 \pm 0.49^{\mathrm{a}, \mathrm{b}}$ & $34.12 \pm 1.4^{\mathrm{a}, \mathrm{b}}$ & $27.6 \pm 2.0^{\mathrm{b}}$ & $18.9 \pm 1.71^{\mathrm{b}}$ & $14.2 \pm 1.6$ \\
\hline T-1 & $\begin{array}{c}\text { Extract }(200 \mathrm{mg} / \mathrm{kg})+ \\
\text { Scopolamine }(1 \mathrm{mg} / \mathrm{kg})\end{array}$ & $32.84 \pm 0.7^{\mathrm{b}}$ & $25.91 \pm 0.7^{\mathrm{c}}$ & $19.83 \pm 1.84^{\mathrm{c}}$ & $13.1 \pm 1.65^{\mathrm{c}}$ & $9.9 \pm 1.64$ \\
\hline T-2 & $\begin{array}{c}\text { Extract }(400 \mathrm{mg} / \mathrm{kg})+ \\
\text { Scopolamine }(1 \mathrm{mg} / \mathrm{kg})\end{array}$ & $33.34 \pm 0.6^{\mathrm{b}}$ & $28.18 \pm 1.0^{\mathrm{b}}$ & $21.3 \pm 1.33^{\mathrm{c}}$ & $14.7 \pm 1.56^{\mathrm{b}}$ & $10.3 \pm 1.6$ \\
\hline T-3 & $\begin{array}{c}\text { Extract }(800 \mathrm{mg} / \mathrm{kg})+ \\
\text { Scopolamine }(1 \mathrm{mg} / \mathrm{kg})\end{array}$ & $34.7 \pm 0.63^{\mathrm{b}}$ & $30.8 \pm 1.87^{\mathrm{b}}$ & $23.46 \pm 1.5^{\mathrm{a}, \mathrm{b}, \mathrm{c}}$ & $16.3 \pm 1.75^{\mathrm{b}}$ & $11.6 \pm 0.96$ \\
\hline
\end{tabular}

$\mathrm{a}=\mathrm{p}<0.05$ when compared to Vehicle (Normal) group, $\mathrm{b}=\mathrm{p}<0.05$ when compared to Scopolamine (Treated) group, $\mathrm{c}=\mathrm{p}<0.05$ when compared to Group II

\subsubsection{Estimation of Acetylcholinesterase by microplate assay}

The results obtained from the estimation of \% inhibition of acetylcholinesterase enzyme by using microplate reader showed that those animals challenged by scopolamine after pre-treatment with extract at different doses showed a significant increase in \% inhibition when compared to the normal and the scopolamine treated group as shown in Table 8 .

\section{Discussion}

L. leucocephala is a common plant which is used as animal fodder and a rich source of protein. Our assumption that the leaf extract will be nontoxic and safe was validated by the acute oral toxicity study. Absence of CNS, autonomic or any other adverse effects enabled us to select three doses, the highest one being $800 \mathrm{mg} / \mathrm{kg}$.

The qualitative estimation of the phyotcostituents showed the presence of alkaloids, carbohydrates, saponins, tannins, steroids, triterpenoids, flavonoids, and proteins. However, we have not carried out quantitative study of these components. Neither the activity of isolated compounds were studied which is one of the limitations.

The study results show that the extract of $L$. leucocephala leaves could improve the learning and memory in experimental rats. The ability of the plant extract to overcome the amnesia produced by scopolamine was assessed by determining the transfer latency, inflexion ratio, \% alteration, and several arm entries using established maze models using rats. Rats are quick learners and can be trained more effectively.

Induction of amnesia and cognition deficit using scopolamine is an established and validated procedure. The compounds which can reverse the effect of scopolamine certainly could be promising drugs for overcoming memory impairment. In this regard, the action of $L$. leucocephala extract at different dose levels is comparable to that of memory enhancing drug piracetam.

Loss of memory and cognitive functions in diseases such as Alzheimer's is attributed partially to the impairment of cholinergic system. Depletion of acetylcholine (ACh) level in brain and its enhanced metabolism by acetyl cholinesterase enzyme (AChE) is observed in such patients. As a consequence, any drug which can prevent the metabolic degradation of Ach by $\mathrm{AChE}$ could be a potential nootropic agent. Hence, we studied the level of AChE in rat brain after treating with different doses of the extract in normal and scopolamine challenged rats. The results reveal that the extract significantly reduces the activity of AChE.

As stated in the introduction, many plants show nootropic activity, can improve memory and perhaps retard loosing memory as age advances. L. leucocephala can also be a promising candidate. The study was limited by the time and funding resources as it was an academic project. The study lacks quantitative data of the phytoconstituents. Isolating the compounds and testing them may give us an active compound. The histopathological data of rats' brain could be added.

\section{Conclusions}

Based on the obtained results, it can be concluded that the ethanolic extract of the leaves of L. leucocephala showed significant nootropic potential in scopolamine-induced amnesic rats. The nootropic activity was found in both in-vivo and in-vitro models. Further studies can be carried out to establish the exact mechanism involved in the nootropic activity of the plant. 


\section{Acknowledgments}

The authors are thankful to Nitte (Deemed to be University) for their support during the research work.

\section{Author's Contribution}

JM and CSS designed the study, JM collected the data, JM and SC carried out the analysis of data, CSS approved and verified the procedure and the obtained data, JM and SC prepared the draft manuscript, CSS corrected and approved the final copy.

\section{Competing Interest}

None of the authors have any competing interest in publishing the findings of this study.

\section{Availability of Data and Material}

The additional data will be provided by the corresponding authors on request.

\section{Funding}

This original work did not receive any funding, grants or financial support.

\section{REFERENCES}

[1] Ambikar DB, Harle UN, Khandare RA, Bore VV, Vyawahare NS. Neuroprotective effect of hydroalcoholic extract of dried fruits of Trapa bispinosa Roxb on lipofuscinogenesis and fluorescence product in brain of D-galactose induced ageing accelerated mice. Indian J Exp Biol., Vol.48, No.4, 378-82, 2010.

[2] Preeti K, Rawat MSM. Comparative nootropic effect of Evolvulusalsinoides and Concolvuluspluricaulis. Int $\mathrm{J}$ Pharm Bio Sci., Vol.2, No.1, 616-621, 2011.

[3] Wayne AW. Human learning and memory. Ann Rev Psycho., No.32, 5-52, 1981.

[4] Shelton HM, Brewbaker JL. Leucaena leucocephala - the most widely used forage tree legume. Invasive Species Compendium, 15-29, 1994.

[5] Rasmia AH, Wafaa AT, Lobna MA. The flavonoid constituents of Leucaena leucocephala growing in Egypt and their biological activity. Afr $\mathbf{J}$ Tradit Complement Altern Med., Vol.11, No.1, 67-72.

[6] Chung YC, Yau DW. Polyprenol from the whole plants of Leucaena leucocephala. J Environ Prot., No.1, 70-72, 2010.
[7] Poonam S and Pushpa RK. Leucaena leucocephala - A nutrition profile. Available from: http://www.archive.unu.e du/unupress/food/8F163E08.html. [Accessed on 30 September 2020].

[8] Chung YC, Yau DW. Steroids from the whole plant of Leucaena leucocephala. Am J Anal Chem., No.1, 31-33, 2010.

[9] Syamsudin, Ros Sumarny, Partomuan Simanjuntak Anti-Diabetic Activity of Active Fractions of Leucaena leucocephala (Imk) Dewit Seeds in Experimental Model. Eur J Sci Res., Vol.43, No.3, 384-391, 2010.

[10] Amira MGE, Amer H, Helmy WA, Ragab HM, Roba MT. Antiproliferative and Cancer-Chemopreventive Properties of Sulfated Glycosylated Extract Derived from Leucaena leucocephala. Indian J Pharmaceut. Sci., Vol.69, No.6, 805-811, 2007.

[11] Ademola IO, Idowu SO. Anthelmintic activity of Leucaena leucocephala seed extracts on Haemonchus contortus infective larvae. The Veterinary Record. N0.158914, 485-486, 2006.

[12] Aderibigbe SA, Adetunji OA, Odeniyi MA. Antimicrobial and Pharmaceutical Properties of The Seed Oil of Leucaena leucocephala. Afr J Biomed Res., Vol.14, No.1, 63-68, 2011.

[13] Ter Meulen U, Struck S, Schulke E, El Harith EA. A Review on the Nutritive Nalue and Toxic aspects of Leucaena leucocephala. Tropical Animal Health and Production, Vol.4, No.2, 113-126, 1979.

[14] Singh TT, Sharma HM, Devi AR, Sharma HR. Plants used in the treatment of piles by the scheduled caste community of Andro village in Imphal East District, Manipur (India). J Plant Sci., Vol.2, No.3, 113-119, 2014.

[15] Talubmook C, Buddhakala N. Hypoglycemic and Hypolipidemic Properties of Leaf Extracts from Phyllanthus acidus (L.) Skeels, Leucaena leucocephala (Lam.) de Wit. and Psidium guajava (L.) in Streptozotocin-Induced Diabetic Rats. Int J BioSci., Vol.2, No.2, 30-34, 2013.

[16] Dzoyem JP and Eloff JN. Anti-inflammatory, anticholinesterase and antioxidant activity of leaf extracts of twelve plants used traditionally to alleviate pain and inflammation in South Africa. J Ethanopharmacology, No.160, 194-201, 2015.

[17] Kaplan A, Lavernal LS. Clinical chemistry: interpretation and techniques $1^{\text {st }}$ edition. Philadelphia: Lea and Febiger, 1983.

[18] Yin HH, Santa E. Potential herbal medicines and drug interactions. Available from: http://www.stuartxchange.co m/ipil-ipil.html. [Accessed on 30 September 2020].

[19] Sreemantula S, Nammi S, Kolanukonda R, Koppula S, Boini KM. Adaptogenic and nootropic activities of aqueous extract of Vitis vinifera (grape seed): an experimental study in rat model. BMC Complement Altern Med., Vol.19, No.5, 1, 2005. doi: 10.1186/1472-6882-5-1.

[20] Ropacki SA, Patel SM, Hartman RE. Pomegranate Supplementation Protects against Memory Dysfunction after Heart Surgery: A Pilot Study. Evid Based 
Complement Alternat Med., No.932401, 2013. doi: $10.1155 / 2013 / 932401$.

[21] Soman I, Mengi SA, Kasture SB. Effect of leaves of Butea frondosa on stress, anxiety, and cognition in rats. Pharmacol Biochem Behav., Vol.79, No.1, 11-16, 2004.

[22] Raina P. Effectiveness of Cholinesterase Inhibitors and Memantine for Treating Dementia: Evidence Review for a Clinical Practice Guideline. Ann Intern Med., Vol.148, No.5, 379, 2008.

[23] Bhattacharjee A, Shashidhara SC, Saha S. Nootropic activity of Crataeva nurvala Buch-Ham against scopolamine induced cognitive impairment. EXCLI J., No.14, 335-345, 2015.
[24] Elman GL. Tissue sulphydryl groups. Arch Biochem Biophys, No.82, 70-77, 1959

[25] George LE, Courtney D, Andres V. Featherstone RM. A New and Rapid Colorimetric Determination of Acetylcholinesterase Activity. Biochem Pharmacol., No.7, 88-95, 1961.

[26] Ghosh MN. Fundamentals of experimental pharmacology. $7^{\text {th }}$ edition. Kolkata: Hilton and company, 149-156, 2005.

[27] George LE, Courtney D, Andres V. Featherstone RM. A New and Rapid Colorimetric Determination of Acetylcholinesterase Activity. Biochem Pharmacol., No.7, 88-95, 1961. 